\title{
Organizational Control via ERP system in Tunisia : The State of art and progress
}

\author{
Donia LOUIZI ép. FEKI \\ Assistant Professor of Management, University of Sfax \\ Faculty of SCIENCES de SFAX \\ E_MAIL :donilo2002@yahoo.fr
}

Received date: 12 March 2019; Accepted date:15 July 2019; Published date: 24 September 2019

Academic Editor: Sanaa Boukhari

Copyright (C) 2019. Donia LOUIZI ép. FEKI. Distributed under Creative Commons CC-BY 4.0

\begin{abstract}
This research provides a framework for the analysis; it allows identifying the organizational impact of the ERP adoption on the management controllers' work. As a first step, the purpose is to recognize the factors that affect the decision of the adoption, in order to study in a second step the impact of this decision on the skills development of the management controllers. The conceptual framework used for this research, is inspired from the work in the field of the contingency theory of Weill and Olson (1989) and the theory of innovation diffusion of Rogers (1995). The empirical validation is based on a survey carried out on about 100 Tunisian firms that have adopted different ERP models since 2002. The survey's main findings of the empirical study express the relevance of the conceptual model as a key global instrument for the approach; the results confirmed the managerial impact on the decision of the adoption. A decision that highlights the management controller's skills in reporting and information systems by using new methods and indicators of participation to the organization's management.
\end{abstract}

Keywords: Enterprise Resource Planning (ERP), Information System, Organizational Impact of Adoption, Management Controllers Competencies.

\section{Introduction}

The company undergoes several changes in order to follow the evolution of its interactions; it must be in constant vigil with its macro and micro environment. The use of information and communication technologies is not new for Tunisian companies but is still an increasing priority to be prepared for new needs. The company has initially looked to develop its Information System "IS" within its organizational structure, and then it has adopted various technologies that allow it to thrive and shine on its external environment.

The adoption of information and communication technologies in general and the Enterprise Resource Planning ERP system in particular, facilitates the organizational change. The transformation of the

Cite this Article as : Donia LOUIZI ép. FEKI (2019)," Organizational Control via ERP system in Tunisia : The State of art and progress", IBIMA Business Review, Vol. 2019 (2019), Article ID 258310, 
organization's management procedures leads us to reflect on the organizational change caused by the introduction of the ERP system. Based on these elements of the aforementioned context, this work was proposed to be carried out to determine the adequacy of the organizational control and the ERP system.

To what extent does the adoption of ERP improve the organizational control of Tunisian companies?

\section{Organizational impact of ERP System Adoption}

The review of the literature leads the authors to highlight the contribution of the innovations diffusion theory dealing with the introduction of information technologies, as well as the model of success of the information system of Delone Mclean (1992), the Contingency theory dealing with the impact of the adoption of information technologies on the management control function, starting from other works [Tsai, Lee, Shen and Lin (2012); Kallunki, Laitinen and Silvola (2011); Su.Y.F and Yang.C (2010); Chapman and Kihn (2009), Martin and Poussing (2007); Uwizeyemungu and Raymond (2004); Raymond and Jutras (2003); Bradford and Florin (2003), Scapens and Jazeyri (2003); Granlund and Malmi (2002), Raymond et al. (2002); Case (2002, 2004); Ariss et al. (2000); Rongé (2000), Anthony (1988)] who study the organizational impact of the adoption of information technologies in general and the ERP system in particular on the function of management controllers. Through this review of the literature hypotheses have been come up with and their interaction allowed to conceiving a theoretical proposition (a model). The hypotheses and theoretical proposition will be tested for empirical validation.

These models and theories form a support to the theoretical basis of the work carried out and to which this work is inspired.

To adapt to the new requirements of the technological environment, any organization seeks to modernize its information system by integrating a multitude of systems including the ERP system. The implementation of this system entails several changes namely a change in work procedures, a change in communication habits, in the organization of processes, and a change in the organizational impact on the company.

Reix (2004) stated that "information systems are organization-related". The adoption of this system causes repercussions at the organizational level. Davenport (1998) pointed out that "an ERP system, by its intrinsic nature, imposes its own logic on the strategy, organization and culture of the enterprise", Assuming this definition, it follows that the introduction of ERP system will cause a change by imposing an organizational logic that adapts to the needs of the system. Two major elements will be affected namely the information systems and the organizational processes of the company. In this sense, Davenport (1998) stated that "the consideration of organizational aspects is one of the key success factors of an ERP system". Davenport (1998), Granuld and Malmi (2002) defined the ERP system as "a set of integrated resource control tools that circulate throughout the organization".

The ERP system has an effect on the organization; it affects the decision process and therefore causes a change in the control processes in the company. Indeed, as a result of outsourcing to the outside world, companies are increasingly looking for solutions that allow them to respond to the needs of the market by adopting powerful organizational control tools to help them better manage the relationships with their different partners at reasonable costs (Baglin, G., Lamouri, S., Thomas, A. 2015).

The ERP system has been successful in companies; Davenport (1998) defined "an ERP system as a system that allows a better flow of information, centralization and control of this information, allowing to achieve productivity gains, and to offer competitive advantages." It is also in this context that Rowe (1999) stated that "the implementation of the ERP system is 
accredited with certain essential qualities that improve the management control function".

\section{Theoretical Foundations}

The evaluation of the determinants of the ERP system adoption and its impact on organizational control has been addressed in the literature by authors describing the determinants of adoption of an innovation and the ERP system; other writings have demonstrated the impact of adoption on organizational control.

Among these works, this research has examined Rogers' theory of innovation diffusion (1983 and 1995) which presented the determinants of an innovation adoption, the contingency theory of Kast and Rosenzweig (1973), and the Davis technology acceptance model (1989).

These models and theories have been applied to the domains of information systems by several researchers, they constitute the foundations of the theoretical base of the works carried out and of which this work is inspired.

\section{Models of Innovation Adoption}

The analysis seeks to explore the determinants affecting adoption in Information Technology to identify the determinants of business adoption of the ERP system.

\section{- Adoption of innovation}

"The decision-making process of adopting an innovation is the process by which an individual, or any other unit of analysis, moves from an initial knowledge of innovation to the formation of an attitude toward that innovation; then the decision to adopt or reject, the introduction of the new idea and, finally, the confirmation of that decision "Rogers (1995).

The adoption process based on the individual dimension of Rogers' work (1995) has five stages. Rogers (1995) defined adoption as "a decision-making process in which an individual or organization agrees to use an innovation to achieve a goal." Rogers (1995);
In her research, Pelletier (2005) illustrates the company's ability to innovate from an organizational point of view according to Rogers (1995).

In the decision-making process at the organizational level, Rogers (1995) recognizes two major phases consisting of five stages.

Being inspired by the decision-making process at the organizational level Rogers (1995) proposes three categories of variables favoring the organizational capacity to innovate. Three characteristics were identified by Rogers (1995), the first presenting the individual characteristics of the leader. The second illustrating the characteristics related to the internal structure of the company. And finally, the third reflects the external characteristics of the company. This illustration allows us to specify that the process of adopting an innovation or technology is caused by external pressures that subsequently materialize at the organizational level Pelletier 2005; Ducrocq, C., Bironneau, L, The Roy, B. Thenet, G (2011).

The effect of the adoption of the ERP system on the management control function

\section{- The study of Su .Y.F et Yang.C}

In a study presented by Su.YF and Yang.C (2010), the authors tried to present the impact of the adoption of ERP on the evolution of skills of Supply Chain Management (SCM), indeed the ERP as well as the SCM represent information technologies having a considerable impact according to the theoretical literature for the improvement of the organizational performance Su.YF and Yang.C (2010).

The authors proposed a model that combines the advantages of ERP with an impact on the competence of GCS.

To clarify the relations of the ERP and the SCM, the authors used the model of structural equations to study the 9 hypotheses proposed by the model with the Taiwanese companies as a sample of 
the investigation. "Taiwanese companies have been booming for the last two decades and have the ability to cooperate with all SCM members and respond to any unforeseen changes" Su.Y.F and Yang.C (2010).

The results show a close interrelationship between the advantages of implementing ERP systems and the skills required on SCM. The results show that the beneficial effects of ERP on SCM do not necessarily lead to a better overall competence of GCS.

The study confirms that operational benefits, the business process and strategic benefits can enhance the company's skills in terms of business process integration, customer relationship and the improvement of system control and planning.

Although the model has been verified and validated, some limitations seem to exist. Indeed, the authors recommend checking the model on other samples including companies from other countries such as Korea, China and Singapore.

\section{The study of Kallunki, Laitinen et Silvola}

The study by Kallunki, Laitinen and Silvola (2011) examines the effects of the adoption of the ERP system on the financial and nonfinancial performance of the company.

The authors study the role of the formal system as well as the informal system as a mediating mechanism between the adoption of the ERP system and its future performance. "With the adoption of the ERP system companies can achieve progress by improving productivity" [Hunton et al. (2003); Kallunki, Laitinen and Silvola, (2011)] and "this with better designed information systems" [Arnold (2006), Kallunki, Laitinen and Silvola (2011)].

"Companies should be able to translate the benefits of ERP adoption into better financial and non-financial performance" [Hunton et al. (2003); Nicolaou (2004), Nicolaou and Bhattacharya (2006, 2008),
Velcu (2007), Wier et al. (2007); Kallunki, Laitinen and Silvola (2011)].

In this context, the management accounting literature suggests a wider use of the management control system [Chapman (2005); Chapman and Kihn, (2009), Kallunki, Laitinen and Silvola (2011)].

Based on these arguments, the authors developed a model by referring to a sample of 70 Finnish firms investigated empirically.

The results of the study demonstrate that formal management control systems can act positively as an intermediate mediating variable between the adoption of the ERP system and the non-financial performance of the enterprise. "However, the informal system of management control does not have the effects of mediation" (Kallunki, Laitinen and Silvola, 2011). The study also demonstrates a close relationship between financial performance and non-financial performance.

The authors state that these results are very important for "the improvement of future performance with the adoption of the ERP system, given the shortcomings of the previous literature which is very limited on this subject" (Kallunki, Laitinen and Silvola, 2011) .

The results also show that the impact of adopting the ERP system will "affect the future performance of the company over the long term and it is through the formal and informal management control systems that companies can achieve their goals "(Kallunki, Laitinen and Silvola, 2011).

Some limitations can be retained in the research of Kallunki, Laitinen and Silvola (2011). Indeed, several variables were introduced in the model; it is within this framework that they recommend to limit the number of variables in a later study. A second limitation is that it is imperative to actually check the modules adopted by the companies surveyed before proceeding to the questionnaire. Indeed some surveyed companies may have introduced only a few modules which can skew the result of the impact of the ERP system adoption on the performance of the company. 
Despite the limitations of this research, it provides a conceptual framework that suggests using the formal and informal management control system for financial and non-financial performances. The results support the scopes of (Chapman and Kihn 2009, Kallunki, Laitinen and Silvola, 2011), which show that better management satisfaction can be achieved with the adoption of the ERP system, by allowing a better financial performance and non-financial even if performance is not directly improved.

The study also confirms the results of Nicolaou (2004) illustrating the improvement of the company's performance following the adoption of the ERP system by introducing the parameters of the formal and informal management control system.

\section{Specific conceptual framework}

The purpose of this article is to formulate a framework illustrating the impact of the adoption of the ERP system on organizational control.

\section{Variables and hypotheses of research}

Once the variables are justified and the relationships are identified, it is necessary to summarize the hypotheses used in this research: The following table illustrates the different hypotheses that will be analyzed.

Tableau 1: Research hypotheses

\begin{tabular}{|l|l||}
\hline H1 & The relative advantage positively impacts the adoption of the ERP system. \\
\hline \hline H2 & $\begin{array}{l}\text { Operational and technological compatibility positively impacts the adoption of } \\
\text { the ERP system. }\end{array}$ \\
\hline \hline H3 & $\begin{array}{l}\text { The complexity of the system positively impacts the adoption of the ERP } \\
\text { system. }\end{array}$ \\
\hline \hline H4 & $\begin{array}{l}\text { The company (business) environment positively impacts the adoption of the } \\
\text { ERP system. }\end{array}$ \\
\hline H5 & Innovation capacity positively impacts the adoption of the ERP system. \\
\hline \hline H6 & $\begin{array}{l}\text { The management commitment has a positive influence on the adoption of the } \\
\text { ERP system. }\end{array}$ \\
\hline \hline H7 & The user satisfaction has a positive impact on the adoption of the ERP system. \\
\hline $\mathbf{H 8}$ & $\begin{array}{l}\text { The skills in reporting and the use of the new methods of information } \\
\text { processing are essential for the management controllers using ERP. }\end{array}$ \\
\hline \hline H9 & $\begin{array}{l}\text { Skills in the implementation of indicators and participation in the piloting are } \\
\text { essential for the management controllers using ERP. }\end{array}$ \\
\hline \hline H10 & $\begin{array}{l}\text { Skills in budget management, transparency and flexibility of information are } \\
\text { paramount and essential for the management controllers who use ERP. }\end{array}$ \\
\hline H11 & The experience of supervisors is a particularly important skill. \\
\hline \hline H12 & $\begin{array}{l}\text { The information system skills of management procedures are particularly } \\
\text { important conditions for the management controllers who use ERP. }\end{array}$ \\
\hline H13 & $\begin{array}{l}\text { The management controller who uses ERP has general missions not related to } \\
\text { the traditional management controllers' activities. }\end{array}$ \\
\hline \hline
\end{tabular}




\section{Conceptual model}

The theoretical developments presented in the preceding sections contribute to presenting the general context of the effect of the ERP system adoption on the management control function and to circumscribe a specific framework to study all the aspects relating to the research problem to explore, in particular, the organizational changes observed in the management control function following the adoption of the ERP system.

The proposed research model aims to reduce and optimize the theoretical models presented in the literature by certain numbers of researchers and present the appropriate variables to the chosen problem.

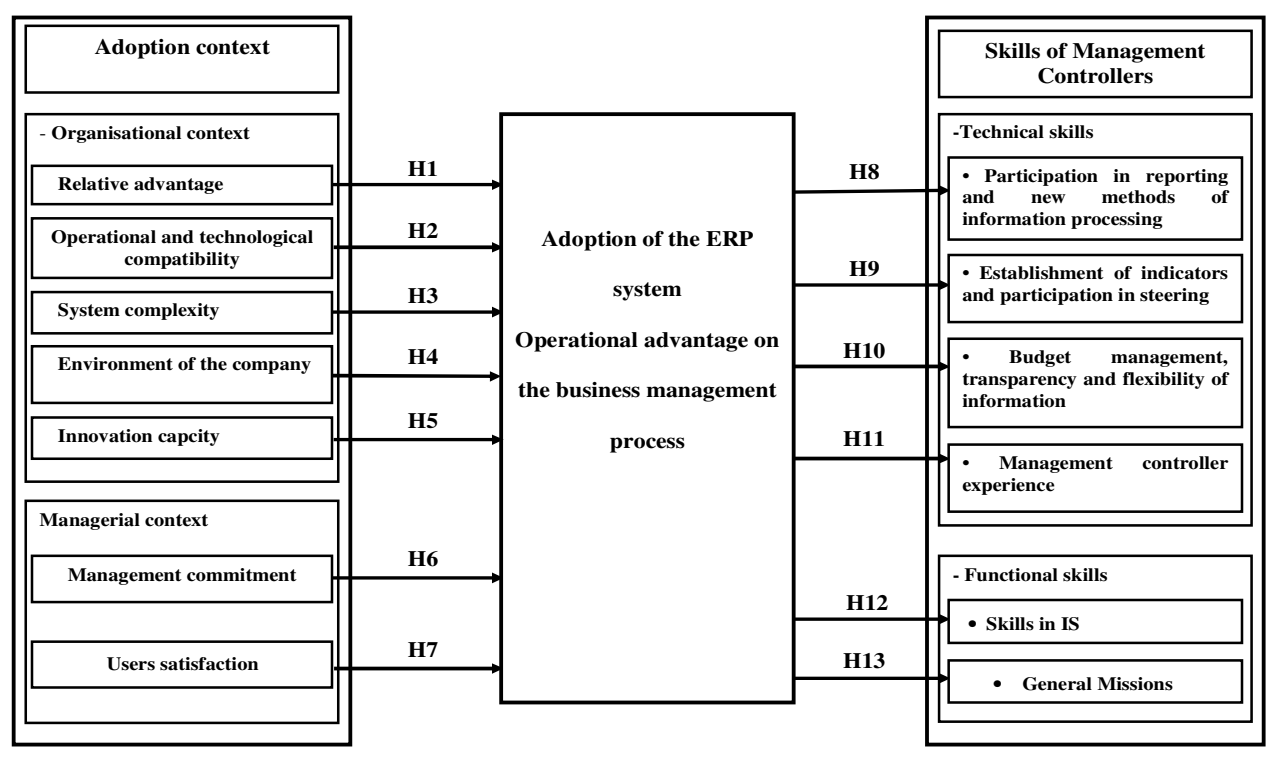

Figure 7: The conceptual model of research: organizational impact of the general context of ERP adoption on the evolution of the management control function

\section{Methodology and field of research}

To answer the selected research problem, the mother population includes all the Tunisian companies that have adopted the ERP system. The objective of the research is to establish a concordance between the assumptions used in the proposed conceptual model. The choice of the target population is made in two phases.

The first phase is to diagnose the population of Tunisian companies that have already adopted the ERP system. To explore these companies, our key sources of information are the main ERP system vendors who are present in Tunisia namely, the companies "DISCOVERY", and
"TIMSOFT" as well as other companies related to our own network of knowledge, it is mainly composed of the Poulina group, the company "GRANUPHOS", the Tunisian telecommunication operator "OOREDOO", "HENKEL" and the "TUNISAIR Company".

Publishers who have contributed to the exploration of the selected sample of companies are service companies and computer engineering firms. Indeed, the company "DISCOVERY" was created in 1993, by a shareholding of companies, whose main task was to contribute to the implementation of integrated IT management solutions for medium and large companies. 
The second publisher chosen is the company "TIMSOFT", and it is also a service company. Its wide functional coverage and the ease of implementation of the proposed solutions are one of the assets of this company. The authors were able to make contacts with this company, through the company located in metropole of Tunis, as well as through seminars that it organized.

A second phase consisted in selecting a database of companies and grouping the top 100 companies in Tunisia by adapting it in order to keep companies that have adopted the ERP system, especially the financial and management control module. This choice allowed compiling a list of seventy companies as a sample for the survey.

The results of the cross-sectional analysis of the definition and representativeness criteria of the sample show that the majority of respondents are management controllers and ERP project managers. Most of the questioned companies belong to a group, they are large companies with a turnover exceeding 6 Million Dinars, it should also be noted that $46.7 \%$ of the companies surveyed have more than 5 modules and 31\% companies acquired the ERP between 2000 and 2001.

Before presenting the tools and methods for analyzing the data collected, it is now necessary to describe the technique adopted and the scales of measurement of the search variables.

\section{Search Results}

Several variables are identified as having an organizational impact on the management control function. The scale chosen for measuring items in this research is the Likert scale. A questionnaire was presented to a panel of experts operating in the field for final approval before conducting the survey. The panel of judges consists of two teachers, a specialist of the company "TIMSOFT", a specialist of the company "DISCOVERY" and a General Chair of a Tunisian company that has already adopted the ERP system.

\section{Exploratory and Confirmatory Analysis}

The review of the literature has allowed us to identify several scales reflecting the different levels of research. The scales used were the subject of an exploratory factor analysis.

In this part of the analysis, "principal component analysis (PCA)" is used. Given the large number of items selected, it is imperative to look for a method that allows to purify the items and to retain only the most significant items to the result of the research. Indeed, a questionnaire survey was opted for. The validation of the scales of measurement requires studying their dimensionality, their reliability and their validity. The study of dimensionality is carried out by means of exploratory factor analysis. "The reliability or internal consistency of our measurement scales is examined through the Cronbach alpha coefficient" Gavard P. et al. (2008, p218), Churchill (1979).

The results of the study of the dimensionality, the reliability and the convergent validity of each scale of measurement will be exposed by means of an exploratory factorial analysis of each scale with the examination of its reliability.

However, such an analysis requires the verification of a number of conditions including, in particular, the KMO "KaiserMayer-Olkin" index which is defined as "a generalized measure of the partial correlation between the variables of the study" Stafford and Bodson (2006, p.80), Bartlett's test and the quality of item representation.

After collecting the questionnaires during the exploratory phase, each measuring instrument was processed with the SPSS 21 data processing software. To do this, the approach that was followed is to first examine the data, then proceed to a Principal Component Analysis (PCA) and finally validate the results by checking the cronbach's alpha value of each variable revealed by the Principal Component Analysis. 
For data analysis, we used the structural equations approach through the AMOS software, in order to respond to the approach of the conceptual model chosen for the research work.

Another step is the confirmation of the model, using the AFC technique. Following the Exploratory Factor Analysis and Reliability Analysis we will try to show "to what extent alternative models explain the relationships between items in a scale" (Akrout, 2010). This technique is used to test the validity of hypothetical relationships that have already been justified (Roussel et al., 2002). There are many attempts to develop unbiased reliability measurement tools, and that of Joreskog (1971) is the most widely used "(Akrout, 2010, p225). Exploratory Factor Analysis "identifies the structure of a scale" (Akrout, 2010), while Confirmatory Factor Analysis "confirms this structure"

To do this, the authors proceeded by the use of Structural Equation Methods(SEM) through the quality adjustment criteria of the model provided by the AFC including Roussel et al. (2002) "group into three family groups respectively relating to: absolute indices, incremental indices, parsimony indices and convergent and discriminant validities". The selected indices are:

-Three absolute indices: GFI, AGFI, RMSEA (Akrout, 2010, p171 ... 174)

-Two incremental indices: NFI, CFI (Akrout, 2010, p177)

-An index of parsimony: Chi-Two normed

The following table summarizes the various indices that have been selected for "the adjustment of the model at the global level as well as the thresholds of the various indices chosen", (Akrout 2010, Roussel et al 2002 Kline 2005, Bentler 1988, Byrne 1994, Premkumar and King 1994).

The path followed for the confirmatory analysis is to first check the adjustment indices, then a reliability analysis of the scale followed by the analysis of the convergent validity and finally the study of the discriminant validity of the measuring scale.

For the analysis of data, we intend to use the structural equations approach through the AMOS software, in order to respond to the approach of the conceptual model chosen for our research work.

The empirical study of the conceptual model in question consists of direct relationships between independent and dependent variables. The appropriation of the modeling method by the structural equations allowed to testing the relationships between the structural model variables treated from the conceptualization.

The authors tried to expose and perform a purification of the scales of measurement. A second step was to perform an exploratory and confirmatory factor analysis and then proceed with the structural equation method to test the hypotheses.

\section{Conclusion}

Several companies, notably Tunisian ones, had to restructure their organization by introducing an upgrading plan. These companies have invested in the reengineering of their information process and have adopted state-of-the-art technologies, including the 'ERP' system, which meets the new requirements. The purpose of this article was to study the organizational impact of the adoption of ERP on the evolution of the function of management controllers in Tunisian companies.

The analysis carried out initially dealt with the determinants of adoption of an ERP system; secondly, with the organizational effects of this adoption (how will the introduction of the ERP system change the organization). This research is also devoted to analyze the interactivity of the ERP system and organizational control. In other words, how will this system contribute to the strengthening of the control system and the improvement of the management control function in the organization? and to 
verify, moreover, whether the management controls logic changes following the adoption of the ERP system, while underlining the possible new role to be attributed to management controllers in the organization.

The results of the analysis of the criteria of definition and representativeness of the sample show that the majority of respondents are management controllers and ERP project managers.

Most of the surveyed companies belong to a group and are for the most part large companies with a turnover exceeding 6 MD. The results of the analysis highlight the importance of managerial prerequisites for management commitment and user satisfaction, the importance of technological skills in terms of new reporting methods, and generations of dashboard for the management controllers. The implementation of new indicators for the participation of management controllers in the process of steering operational and strategic decisions has improved significantly with the appropriate use of information systems and especially ERP. At this level of research, it is confirmed that a large proportion of Tunisian companies practice traditional management control by adopting operational and non-strategic steering and reporting techniques. This can be deduced by a strategic choice of managers based on very specific visions of the general context. Despite a strong willingness of managers interviewed, especially management controllers, to improve the control system in their respective services, conflicts were detected mainly by an inability to keep pace with the change that overtakes technological change to an organizational change involving the entire organization. The results reveal the contribution of the management controller of the surveyed companies to the operational objectives by an active and real participation in the decisions of piloting, the programs of operational planning and some strategic operations.

Changing the roles of the controllers will lead to a shift in responsibilities and will require greater willingness to integrate them for full organizational and technological change in the process.

The implementation of the ERP is part of a transversal logic by creating a new vision tending to break the organizational boundaries. New relationships and practices can be developed between different staff members.

This article helps to highlight the importance of management's managerial mobilization, which made it possible to follow the organizational change induced by the ERP system. Despite the resistance to change by some users, ERP managers and project managers have managed to achieve their goal of integrating ERP with the strengthening of the control system in the organization. A control that has become easier with ERP and opportunities offered by this system.

From an operational point of view, the research helped to empirically emphasize the main job of the management controller, through the adopted methods for the treatment of information, their necessary personal and professional skills of the management controllers, their commitment and involvement in the use of information technologies and especially ERP.

The research framework of Kallunki et al. (2011) can be considered for the economic fabric of Tunisian companies, most of them SMEs. Indeed, the model offers relevant arguments of "the impact of the ERP system on financial and non-financial performance over the long term, i.e. it is through the proper use of ERP that formal and informal management control systems can be strengthened and can achieve their goals "(Kallunki et al., 2011).

Most managers of Tunisian companies place much more importance on informal information and that really impact their operational and sometimes even strategic decisions.

The study conducted by Azan (2007) confirms the evolution of management controllers' skills in terms of management 
and control through the adoption of ERP, especially for large companies. Our study also confirms this result; in fact $48.9 \%$ of the surveyed companies are large. This proves that contingency factors are very important, factors that change from one company to another, making it possible to create differences between the controllers from one company to another.

From a strategic point of view, our research has important implications for managers and management controllers by specifying the missions of participation in piloting and reporting. The results offer the latter the alternative of positioning the different practices required by the profession in relation to the field of possibilities using ERP and possibly see the chance of strengthening missions for better control in Tunisian companies.

This reflection leads the authors to confirm the results of the studies conducted by Su.Y and Yang (2010) which state that the strategic advantages of the ERP make it possible to improve the control and planning system of enterprises. this study proposed to consider the management controller as an adviser who is in charge of consulting missions with all the skills necessary for the success of his mission and not as a simple technician (Fornerino, M., Deglaine, J., Godener , A. 2003). Thus, his role is no longer limited to the reporting of information but rather it represents an agent of change (Scapens and Jazeyri, 2003).

The study by Boitier (2004) showed that "the adoption of ERP is part of logic of interactive control. This interactivity brings together the development of interactive control in the organization (Fahy and Linch, 1999, Scapens and Jazayeri, 2003, Boitier, 2004) and the orientation and support of the strategic decision by establishing a control system closer to the operational directors "(Boitier, 2004, Granuld and Malmi, 2002). The results of this study prove the existence of a positive relationship between the adoption of the ERP and its contribution to strengthening the control system in the Tunisian surveyed companies.
Management commitment is a strategic managerial decision involving ERP users for enhanced interactive control across the organization and between different departments of the organization. A system requires a deep adaptation of the organizational culture of the different actors with a strong internal will of change and evolution.

\section{Research Perspectives}

This work has finally allowed the authors to have significant results that can be exploited and verified in the field. Hence, other perspectives can be offered for future research and limitations can be identified to this study.

At the theoretical level, a study of the financial impact of the indicators on the performance of management auditors could perhaps have taken place. Indeed, this research focused mainly on organizational impacts that neglect the financial impact of indicators. Being a considerable financial burden for a company to set up the ERP, it would also be wise in another research framework to study a funding scheme or even a reorganization of investments to adopt an ERP.

A second limitation is the absence of the retroactive effect of the adoption of the ERP on the organizational structures of the management controllers. In general, the adoption of ERP has an impact on the organization in general in terms of organizational mode, and in particular on the structure and strategy department of the management controllers. But this study reveals the absence of the retroactive effect of the adoption of the ERP on the organizational structures of the management controllers. This is the second limit of this research.

Regarding the reflection of the adoption of the ERP system, the utility of the latter remains the same; however, each system uses its own approach, logic, and architecture at the design level in the case of statutory grouping of multiple entities. How then to succeed to migrate on a common ERP or in a simpler way, would it 
be possible to create a layer to converge two ERP systems? In such a practical and problematic case to date, it would be interesting to study the feasibility as well as the investment cost by a longitudinal case study.

With such a system, it would be interesting to study the managerial behavior of the research and development division against the recommendations of the management controllers with a view to invest in innovation.

The highlighting of these limits leads to propose new and relevant research pathways. In order to give more consistency to our results, this research could be expanded by providing reliable management control by creating a universal virtual controller based on a set of parameters inspired by a tested conceptual model. This computerized tool will have the role of verifying the statistics collected with the real state and measuring the efficiency of one ERP compared to another.

The adoption of an ERP is a long process that must be studied in a framework of evolution and growth. Given the particularity of each company to manage and manage internally, there may be a specific module to deal with. A longitudinal study of the ERP system and in particular QPR: Quality Processes Results can be considered by adding more appropriate modules to implement the strategy adopted by the managers and to improve the performance of the processes.

It will also be interesting in the future to focus on another aspect concerning this subject. This is the managerial part, proposing to study the evolution of the professions of managers and managers in interactivity with the ERP system.

\section{References}

1. Anthony R. N. (1988), la function contrôle de gestion; The management control Function, Harvard Business School Press.
2. Anthony R.N., Govindarajan V. (1997), Management Control Systems, McGrawHill, 900 p., 9th Ed.

3. Anthony, R., Welsch, G. et J. Reece, (1985), Fundamentals of Management Accounting, 4ème éd. Irwin.

4. Association Nationale des Directeurs Financiers et de Contrôle de Gestion (2010), Le Contrôle de Gestion. Quels rôles? Quelles compétences ? Quelles évolutions ? Regards croisés sur les pratiques au niveau international, Les ecahiers techniques de la DFCG, avril, 53 pages

5. Azan W. (2002), L'interdépendance entre intégrateur ERP et le métier automobile, La Cible, $\mathrm{N}^{\circ} 91$

6. Azan W. (2007), «Compétence des contrôleurs de gestion, utilisation d'ERP et impératif technologique, une analyse empirique» Colloque de l'Association Francophone de Comptabilité, Poitiers.

7. Azan, W. (2010), «compétence des contrôleurs de gestion, utilisation d'ERP et impératifs technologique, une analyse empirique» Comptabilité et Environnement. France.

8. Baroudi and Orlikowski, (1988) J.J. Baroudi, W.J. Orlikowski A short-form measure of user information satisfaction: a psychometric evaluation and notes on use Journal of Management Information Systems, 4 (4) (1988), pp. 44-59

9. Bassellier, G. et Pinsonneault, A. (1998), "Assessing Top Management Support For Information Technologies: A New Conceptualization and Measure," ECIS, Aixen-Provence, France.

10.Bernier, C., Bareil, C. et Rondeau, A. (2003). Transformer l'organisation par la mise en œuvre d'un ERP : une appropriation à trois niveaux, Gestion, $27(4), 24-33$ 
11.Besson, P. (1999), 'Les ERP à l'épreuve de l'organisation', Système d'Information et Management, vol.4 (4), pp.21-51.

12.Boitier, M. (2004a). "Les ERP : un outil au service du contrôle des entreprises ?". Contribution à un numéro spécial de Sciences de la société, février, $n^{\circ} 61, p p .91-$ 105.

13.Bollecker M. (2007), Système de pilotage et performance in Systèmes de pilotage et performance, ESKA, Paris.

14.Bouchard, L. (1993), "Decision Criteria in the Adoption of EDI." Proceedings of the 14th International Conference on Information Systems, Orlando, Florida, pp. 365-376.

15.Bouquin H. (1994), Les Fondements du Contrôle de Gestion, Que sais-je?, PUF.

16.Bouquin H. (1999), "Contrôle et stratégie" in B. Collasse (coord.), Encyclopédie de Comptabilité, Contrôle, Audit, Economica.

17.Bouquin H., Pesqueux Y. (1999), "Vingt ans de contrôle de gestion ou le passage d'une technique à une discipline", Comptabilité - Contrôle - les 20 ans de l'AFC, Audit, pp.93-105, mai http://www.iaetoulouse.fr/files/162_pdf.pdf

18.Bradford L. Barham, Jean-Paul Chavas, Dylan Fitz1 , Vanessa Ríos-Salas, and Laura Schechter (2014), Risk, Learning, and Technology

Adoption.https://www.aae.wisc.edu/lsche chter/learning.pdf

19.Bradford M., Florin, J. (2003), Examining the role of innovation diffusion factors on the implementation success of enterprise resource planning systems. International Journal of Accounting Information Systems 4 (2003) 205-225.
20.Brancheau J.C. et Wetherbe J.C. (1990), "The Adoption of Spreadsheet Software : Testing Innovation Diffusion Theory in the Context of End-user Computing", Information Systems Research, Vol. 1, $\mathrm{n}^{\circ} 2$, p. 115-143.

21.Bums, T., and Stalker G. M. (1961), The Management of Innovation. London: Tavistock.

22.Chan, R., Rosemann, M. (2001), « Managing knowledge in enterprise systems ». 5th Pacific Asia Conference on Information Systems, (20-22 Juin), Seoul, pp. 916-932.

23.Chenhall, R.H. (2003), "Management control systems design within its organisational context: findings from contingency-based research and directions for the future", Accounting Organisations and Society 28, pp127-168.

24.Chiapello E. (1990), " Contrôleurs de gestion, comment concevez-vous votre fonction?», Echanges, $n^{\circ}$ 92, p. 7-11.

25.Chiapello E. (1996), "Les typologies des modes de contrôle et leurs facteurs de contingence : un essai d'organisation de la littérature", Comptabilité- Contrôle- Audit, Vol.2, $\quad \mathrm{n}^{\circ} 2$, pp.51-74, septembre, http://www.crefige.dauphine.fr/PUBLISH/ invest8.htm

26.Churchill, G.A. (1979), "A paradigm for developing better measures of Marketing construct", Journal of Marketing Research, vol. 16, 1979, pp.64-73

27.Cooper, R.B et Zmud, R.W.(1990), "Information Technology Implementation Research", Management Science, Vol. 36, n 2, p. 123-140.

28.Daft R.L (1992), Organization Theory and design, West Publishing Company.

29.Danziger R., (1995), « 25 ans de contrôle de gestion : l'homme et la fonction », dans 
Le Pen C. et ali., Paris-Dauphine : vingt-cinq ans de sciences d'organisation, Masson, p. 90-103.

30.Davenport, T. H. (1998), "Putting the enterprise into the enterprise system", Harvard BusinessReview, 76, 121-131.

31.Davis F.D, (1989), "Perceived Usefulness, Perceived Ease of Use, and User Acceptance of Information Technology," MIS Quarterly, Vol.13, n³, September, pp.319-340.

32.Deglaine J., Godener A. et Fornerino M. (2003b), " Les compétences clés des contrôleurs de gestion : résultats d'une étude empirique ", Actes du 14ème Congrès AGRH, Grenoble.

33.Deltour, F. (2000), L'innovation dans l'organisation : dépasser les ambiguïtés du concept, Cahier de recherche.

34.Ducrocq C. (2009), Informatique et contrôle de gestion, in Colasse B. (éd.), Encyclopédie de comptabilité, contrôle de gestion et audit, Paris, Economica, 2e éd., p. 977-990.

35.Ducrocq, C.,Bironneau, L, Le Roy, B. Thenet, G (2011), «Les compétences clés des contrôleurs de gestion et leur évolution :vers des compétences humaines a hauteur des compétences techniques», Management et Avenir, Vol.5, n55, pp.3657.

36.Ervard, Y., Pras, B. et Roux, E. (1993), Market, Etudes et Recherches en Marketing, Fondements Méthodes. Paris, Editions Nathan.

37.Fahy M.J. \&Linch R. (1999), "Enterprise resource planning (ERP) systems and strategic management accounting", paper presented at the EAA 22nd Annual Congress, Bordeaux, France, 5-7 May.

38.Fichman R.G, (2000), "The Diffusion and Assimilation of Information Technology Innovations." In Framing the Domain of IT
Management, projecting the future through the past, Zmud, R.W. (Ed.), Pinnaflex Educational Resources, Cincinnati, Ohio, pp.105-127.

39.Germain, C. (2004), "La contingence des systèmes de mesure de la performance: les résultats d'une recherche empirique sur le secteur des PME", Audencia Nantes, Ecole de manangement.

40.Granlund M. \&Malmi T. (2002), « Moderate impact of ERPS on management accounting: a lag or permanent outcome? », Management Accounting Research, Vol 13, mars 2002, pp 185-211.

41.Grover, V. et Goslar, M-D. (1993), "The initiation, adoption, and implementation of telecommunications technologies in U.S. organizations". Journal of Management Information System, Vol. 10, $\mathrm{n}^{\circ} 1$, pp. 351376.

42.Baglin. G., Lamouri.S., Thomas, A. (2015), «Maîtriser le progiciel ERP » Economica.

43.Hassairi, A.F. (2001), Evaluation des investissements en technologies de l'information: Cas des échanges de données informatiques chez les équipementiers automobiles. Thèse de doctorat en Sciences de Gestion, Université des Sciences Sociales, Toulouse I.

44.Ives, B.\& Olson, M.H. et Baroudi, J.J. (1983), "The Measurement of User Information Satisfaction, "Communications of the ACM, Vol. 26, $\mathrm{N}^{\circ} 10$, pp. 785-793.

45.Jordan H. (1998), "Synthèse des résultats de l'enquête HEC / DFCG 1998 : planification et contrôle de gestion dans les entreprises : les outils et les hommes ontils progressé ?", Echanges, $n^{\circ} 146$.

46.Jorissen A., Devinck S. et A.Vanstraelen (1997), « Planning and Control: Are These Necessary Tools for Success? Empirical Results of Survey and Case Research on 
Small and Medium-Sized Enterprises Compared with Research on Large enterprises», Congrès de l'IAAER, Paris.

47.Kalika M. (1987), Structures d'entreprises, réalités, déterminants, performances, Économica.

48.Kast.F., and Rosenzweig, J. (1973), Contingency Views of Organization and Management. Chicago: Science Research Associates.

49.Kimberly, J.R. et Evanisko, M.J. (1981), "Organizational Innovation: The Influence of Individual, Organizational, and Contextual Factors on Hospital Adoption of Technological and Administrative Innovations," Academy of Management Journal, Mississippi State; Dec 1981, Vol. $24, n^{\circ} 4$, pp. 689-714.

50.Kwon T.H. et Zmud, R.W. (1987), "Unifying the fragmented models of information systems implementation", in critical Issues in Information Systems Research, R.J. Boland and R. Hirscheim (eds), John Wiley, Chichester, England, p. 227-251.

51.Lancini, A. (2001), Les déterminants de l'adoption d'un système de gestion des connaissances. Thèse de doctorat en Sciences de Gestion, Université des Sciences Sociales, Toulouse I.

52.Lawrence, P.R, and Lorsch, J. W. (1967), Organizational and Environment.Cambridge, MA: Havard University Press.

53.Lee, A.(1989), «Integrating positiviste and interprétative approaches to organisational research,» Organization Science, Vol. 2, n ${ }^{\circ}$, pp. 342-365.

54.Mahmood, M. A., Burn, J. M., Gemoets, L. A. et Jacquez, C. (2000). Variables affecting information technology end-user satisfaction: a meta-analysis of the empirical literature, Int. J. HumanComputer Studies, vol. 52, 751-771.
55.Mawadia, A., Chapellier, P., Eggrickx, A., (2014) 'ERP et profil d'activités du contrôleur de gestion' IEEE/ASME International Conference on Advanced Intelligent Mechatronics AIM 08-11 juillet.

56. Merchant K. (1981), « The Design of the Corporate Budgeting System: Influences on Managerial Behaviour and Performance ", the Accounting Review, vol. 56, $\mathrm{n}^{\circ} 4$, October, p. 813-829.

57.Meyssonnier F., Pourtier F. (2005), « Les ERP changent-ils le contrôle de gestion ?», 26ème Congrès de l'Association Francophone de Comptabilité, Lille.

58.Pelletier C (2005), l'appropriation des technologies de l'internet et les facteurs critiques de succès en contexte de PME. Mémoire présenté à l'université du Québec à Trois-Rivières, Mars.

59.Pesqueux.,(2002)《 leçon1,Introductionà l'organisation $», \mathrm{CNAM}$, www.cnam.agropolis.fr/DemoDso/cours/L 1_intro.pdf.

60.Peter, J.P. (1981), “Construct Validity: A Review Basic Issues and Marketing Practices," Journal of Marketing Research, Vol. 18, Mai, pp. 133-145.

61.Piva, M., Santarelli, E. et Vivarelli, M. (2004). The skillbias effect of technological and organisational change: evidence and policy implications, Conférence annuelle de l'Association des sciences administratives du Canada (ASAC) - section Gestion de la technologie et de l'innovation, 5-8 juin 2004, Québec, Québec.

62.Raymond, L. et Bergeron, F.(1992), "Personal DSS Success in Small Enterprises." Information \& Management, Vol. 22, pp.301-308.

63.Rogers E., Schoemaker, F. (1971), Communication in innovations: a cross cultural approach, Free Press, New York.

64.Rogers, E. M. (1995), Diffusion of Innovations, Fourth édition, The Free 
Press, New York (editions precedents: 1962, 1971, and 1983).

65.Rogers, E.M.(1983), Diffusion of innovations. 3rd ed. New-York: The Free Press.

66. Rongé, Y. (2000), l'impact des ERP sur le contrôle de gestion: une première évaluation, FINECO, volume 10.

67.Sabgster, A., Leech, S.A. et Grabski, S. (2009), 'ERP implementations and their impact upon management accountants', Journal of Information Systems and Technology Management accounts', Journal of Information Systems and Technology Management accounts'.

68.Sandoe, K., Corbitt, G. et R. Boykin, (2001), Enterprise Intégration, Wiley.

69.Stefanou, C.J. et Athanasaki, M.T. (2012), 'Mangement Accounting Practices in ERP Environments: A Research Agenda',Proceedings of the 9th International Conference on Enterprise Systems, Accounting and Logistics (ICESAL), Greece.

70.Swanson, E.B. (1994), "Information systems innovation among organizations". Management Science, Vol.40, n9, p. 10691092.

71.Szilagyi, A., Jr. and Wallace, M. (1980) Organizational Behavior and Performance.Santa Monica, CA: Goodyear.

72.Talon, S., Zahn, J.-P., Maeder, A., \& Meynet, G. (1997), A\&A, 322, 209 First citation in article | $\underline{\text { ADS }}$
73.Tomas, J.L. (1999), ERP et progiciels de gestion intégrés: Sélection, déploiement et utilisation opérationnelle, 3ème éditions, DUNOD.

74.Tomas, J.L.(2002), ERP et progiciels de gestion intégrés: Sélection, déploiement et utilisation opérationnelle. 3èmeéditions, Dunod.

75.Tomatzky, L.G. et Klein, k.J. (1982), "Innovation Characteristics and Innovation Adoption-Implementation: a Meta Analysis of Findings," IEEE Transactions on Engineering Management, Vol. 29, $\mathrm{N}^{\circ} 1$, pp.28-45.

76.Toranatzky, L.G. et Fleischer, M. (1990), The Processes of Technological Innovation, Lexington Books, Lexington, MA.

77.Vakalfotis, N., Ballantine, J. et Wall, A. (2011), 'A literature review on the impact of Enterprise Systems on management accounting' Proceedings of the 8th International Conference on Enterprise Systems, Accounting and Logistics (ICESAL), Greece, pp. 79-105.

78.Weill, P., Olson, M., (1989), An Assessment of the Contingency Theory of Management Information Systems, Journal of management Information Systems Vol. 6 $\mathrm{n}^{\circ} 1$ in summer, http://www.fba.nus.edu.sg/isworld/exem plaryIS.doc

79.Woodward. J. (1965), Industrial Organization: Theory and Practice. London: Oxford

University,Press.www.aim2003.iut2.upmfgrenoble.fr/Communications/ZAOUIEL\%20AKREMI.rtf 